\title{
偏心および浮き上がりを考慮した球面すべり支承の振動台実験 \\ SHAKING TABLE TESTS ON SPHERICAL SLIDING BEARINGS TAKING ECCENTRICITY AND UPLIFT INTO ACCOUNT
}

\author{
竹内 徹*1, 中村秀司 ${ }^{* 2}$, 内田正颯*3, 吉田道保*3, 松井良太 太4 $^{* 4}$ \\ Toru TAKEUCHI, Hideji NAKAMURA, Masakaze UCHIDA, \\ Michiyasu YOSHIDA and Ryota MATSUI
}

\begin{abstract}
Although rubber bearings are popular for seismic isolation bearings in Japan, Spherical Sliding Bearings (SSB) or Friction Pendulum Bearings (FPB) are also widely used in many countries including U. S. In this paper, shaking table tests on braced frame supported by SSB are carried out, and their dependency on pressure and velocity is examined. Also tests with the eccentric dead loads are conduted, in order to capture lift-up actions at bearings and their performance. Analytical models taking pressure and velocity dependency into accounts are proposed, and their validity against the experimental results are discussed.
\end{abstract}

Keywords: Seismic Isolation, Spherical Sliding Bearing, Shaking Table Test, Eccentricity,Uplift 免震構造，球面寸べり支承，振動台実験，偏心，浮き上がり

\section{1. 序}

我が国において免震構造アイソレータとしては積層ゴム支承が一 般的に用いられているが, 米国においては 1990 年代初頭より球面す ベり支承(Spherical Sliding Bearing:SSB または Friction Pendulum Bearing : FPB)が実用化され, 多くの免震構造に適用されている。SSB は一般的に, コンケイブプレートと呼ばれるステンレスの球面上に テフロン系の表面を持つスライダーを設置して滑らせる免震装置で あり, 振り子運動による復元機構と, 摩擦力を用いた履歴減衰機構 を有している。また，コンケイブプレート曲率により長周期化を実 現する。スライダーが片側の板に固定され，対の球面上を滑るシン グル形式 ${ }^{1)}$ に対し，独立したスライダーが上下のコンケイブプレー 卜球面間に挟まって配置されたダブル形式 ${ }^{2}$ はコンケイブプレート 直径に近い片振幅変形能力を有するため, 最も普及している。軸力 の小さな支承部では変形能力と長周期化の両立が困難な積層ゴムに 対し, 支持重量と無関係に固有周期を決定でき, コンケイブプレー 卜径により最大変形量を調整できる SSB は, 軽量の屋根構造や住宅 の免震化に適している。海外では空港の屋根構造支持部に SSB を挿 入したり ${ }^{3)}$ ，ターミナルビル全体を免震化する事例に用いられてい る ${ }^{4)}$ 。

SSB / FPB に関しては我が国においても 1990 年代より基礎的な実 験が行われるようになり ${ }^{5)}$, 住宅や原子炉建屋を想定した縮小振動 台実験が近年実施されるようになってきている。しかしながら，そ
の利点の一方で下記に述べるような課題が指摘されてきた。

1) 摩擦力が軸力に依存するため, 重量が偏心したり軸力が変動する 支承部では摩擦力が偏在することで上部構造が㧖れ応答する危険 性がある。

2) 支承部が浮き上がった際にはコンケイブプレートがスライダーを 拘束できなくなり，スライダーの動きが予測できなくなる。 そこで, 本研究では偏心および浮き上がりを伴うSSB 付架構の縮 小振動台実験を実施し，上記 1)，2）の課題に対する SSB の応答性 状を確認する。一般的にテフロン系のすべり支承は速度依存性およ

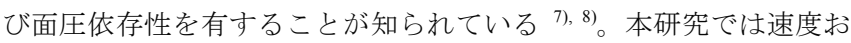
よび面圧を変化させた加振実験を実施することで，SSB の摩擦力に おける速度および面圧依存性を同定し，バイリニア履歴モデルとダ ッシュポッドを組合せることによる力学モデルを構築する。また， 提案した力学モデルを用いて実験結果を再現し，その適用性を確認 するとともに上記 1)，2）の振動応答特性の分析を行う。

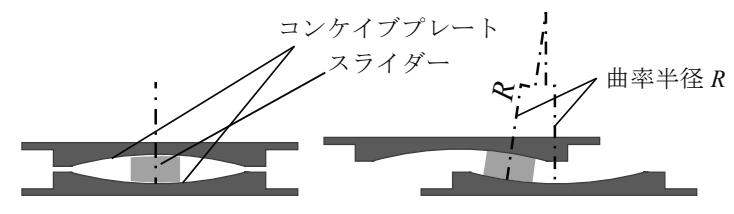

図 1 球面すべり支承の概念図（ダブル形式）
*1 東京工業大学建築学専攻 教授 · 博士 (工学)

*2 新日鉄住金エシジニアリング

*3 東京工業大学建築学専攻 大学院生

*4 東京工業大学建築学専攻 助教・博士 (工学)
Prof., Dept. of Arch. and Build. Eng., Tokyo Institute of Technology, Dr.Eng. Nippon Steel Sumikin Engineering.

Graduate Student, Tokyo Institute of Technology.

Assist. Prof., Dept. of Arch. and Build. Eng., Tokyo Institute of Technology, Dr.Eng. 


\section{SSB の動的加力実験}

課題に対する検証を行う為, 以下に述べるような SSB 付の縮小試 験体架構を製作する。

\section{1 試験体概要}

図 2 に試験体架構を示す。試験体は 1 層 1 スパン分 $(1000 \times 1000$ $\times 600 \mathrm{~mm})$ の鉄骨ラーメン架構とし，X，Y の 4 構面に取り外し可 能な山形鋼ブレースを付加して架構の剛性を変化させる。また, 柱 上部に錘 $(78 \mathrm{~kg} /$ 枚 $)$ を複数積載することで重量を調整する。

図 3 に本実験に用いるSSB を示す。汎用的に用いられるサイズの 約 $1 / 3$ の径とし, 基準面圧 $\left(60 \mathrm{~N} / \mathrm{mm}^{2}\right)$ における速度 $400 \mathrm{~mm} / \mathrm{s}$ での 基準摩擦係数は汎用サイズと同様に 0.047 とする ${ }^{9)}$ 。スライダー径 は $\phi=30 \mathrm{~mm}$ ，コンケイブプレート面曲率半径は $R=2500 \mathrm{~mm}$ とする。 固有周期は式 (1) より, 約 4.5 秒とする。ここに $g$ : 重力加速度で ある。

$$
T=2 \pi \sqrt{2 R / g}
$$

\section{2 動的加力実験概要}

まず，試験体鍾部をロードセルに介して汎用試験フレームへ取り 付けた状態で定振幅波入力による動的加力実験を行い, SSB の摩擦 係数の特性を把握する。また, 後に行う振動台実験における水平応 答せん断力として, 試験体架構におけるブレース軸力および柱の曲 げモーメント分布より評価した層せん断力を用いることの妥当性を 確認する。図 4 にセットアップ図を示す。錘を各柱上部に 5 枚ずつ 積載すると，架構を含めた全重量は $18.62 \mathrm{kN}$ となる。

図 5 に各種測定位置を示す。レーザー変位計を用い, 振動台に対 する SSB 上部ベースプレート変位について測定する。歪ゲージを柱 およびブレースに貼付し, 得られた歪より柱せん断力とブレース軸 力を算出し，それらの水平換算值の和を層せん断力とする。表 1 に 載荷項目を示す。載荷は変位制御で行い，三角波および正弦波を振 動数を変化させながら入力する。水平荷重 $F$ と試験体上部総重量 $W$ の比を等価摩擦係数 $\mu$ と定義し, 式 (2) により表す。

$$
\mu=F / W
$$

図 6 に試験体の歪より評価した層せん断力およびロードセル反力 の時刻歴を示寸。層せん断力はロードセル反力とよく対応しており， 振動台実験において層せん断力は適切に評価されていると判断され る。図 7 に変位一等価摩擦係数関係を示す。横軸の変位は図 5 に示 す変位計の平均值である。等価摩擦係数は 0.1 前後に分布し, 基準 摩擦係数よりも大きくなっていることが分かる。これは実験におけ る面圧が $6.6 \mathrm{~N} / \mathrm{mm}^{2}$ と, 基準面圧の $1 / 10$ 程度になっている影響であ る。同図 (c), (d) より振動数が同じでも, 速度の違いによって等価 摩擦係数にばらつきが出ていることが分かる。また，(a), (b) に見る ように速度の正負が変わる際に，三角波入力において等価摩擦係数 が大きくなっており，慣性力の影響も見られる。以上のように, SSB は一般的なテフロン系すべり支承同様に速度および面圧依存性を有 することがわかる。図 8，9 に表 1 の載荷 No.1 12 により得られた 等価摩擦係数, および文献 9) に示される等価摩擦係数に対する速 度および面圧関係を示す。速度は文献 9) と同様に SSB 上部の值を 用いている。等価摩擦係数は 3 サイクル目における Y 切片正側の值 を用い, 載荷 No.12 については, 3 サイクル目以降の全サイクルを

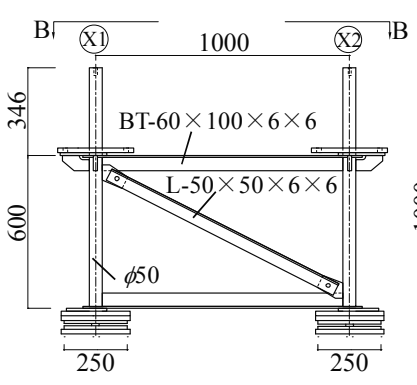

(a) A-A 矢視図

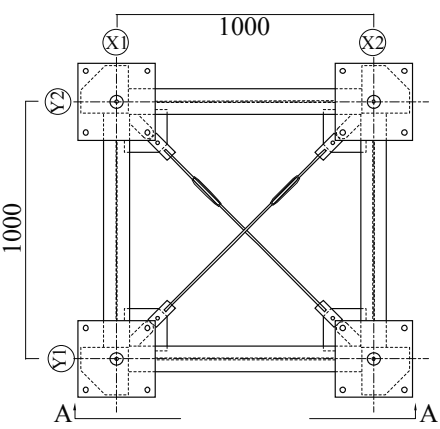

(b) B-B 矢視図
図 2 試験体架構図

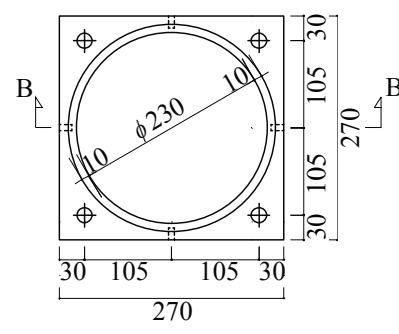

(a) A-A 矢視図

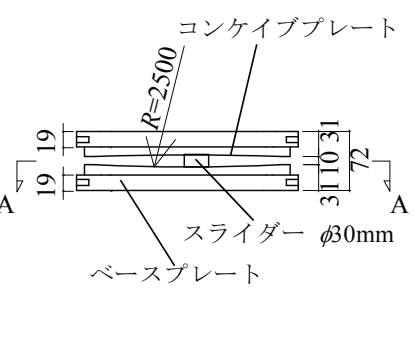

(b) B-B 断面図
図 3 SSB 図（長さ単位：mm）

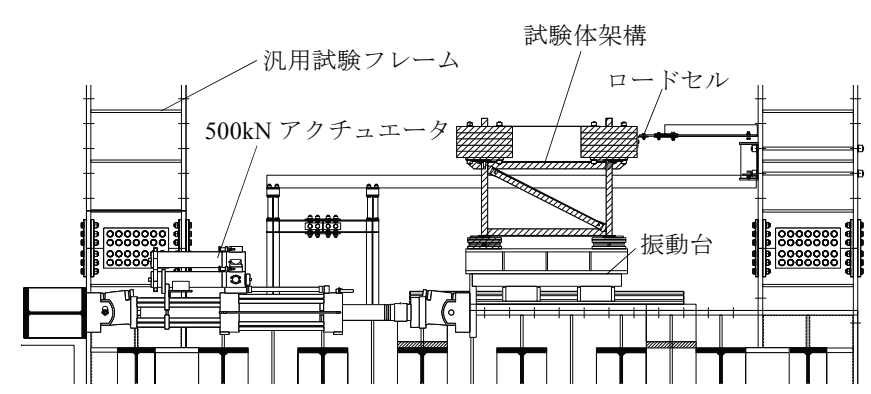

図 4 動的加力実験セットアップ図

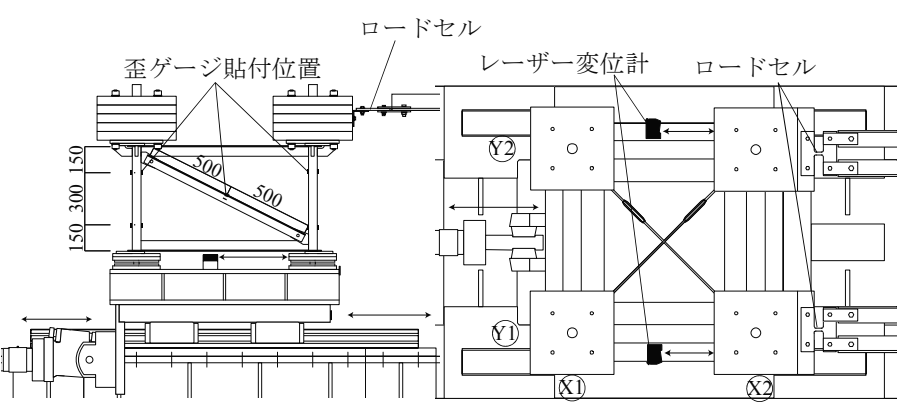

(a) 立面図

図 5 測定位置

(b) 見下げ図

\begin{tabular}{|c|c|c|c|c|c|}
\hline 載荷No. & 振幅 (mm) & 最大速度 $(\mathrm{mm} / \mathrm{s})$ & 振動数 $(\mathrm{Hz})$ & 波形 & サイクル数 \\
\hline 1 & \multirow{8}{*}{180} & 23 & 0.02 & 正弦波 & \multirow{11}{*}{5} \\
\hline 2 & & 22 & 0.03 & 三角波 & \\
\hline 3 & & 102 & 0.09 & 正弦波 & \\
\hline 4 & & 101 & 0.14 & 三角波 & \\
\hline 5 & & 204 & 0.18 & 正弦波 & \\
\hline 6 & & 202 & 0.28 & 三角波 & \\
\hline 7 & & 396 & 0.35 & 正弦波 & \\
\hline 8 & & 403 & 0.56 & 三角波 & \\
\hline 9 & 20 & 40 & 0.5 & \multirow{3}{*}{ 三角波 } & \\
\hline 10 & 50 & 100 & 0.5 & & \\
\hline 11 & 100 & 200 & 0.5 & & \\
\hline 12 & 100 & - & $0.2-0.5$ & 三鱼波 & - \\
\hline
\end{tabular}

表 1 動的加力実験載荷項目 


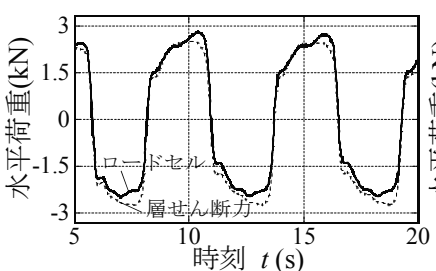

(a) $\pm 180 \mathrm{~mm}, 0.18 \mathrm{~Hz} ，$ 正弦波

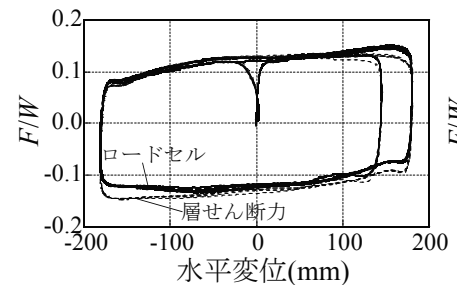

(a) $\pm 180 \mathrm{~mm}, 0.18 \mathrm{~Hz}$, 正弦波

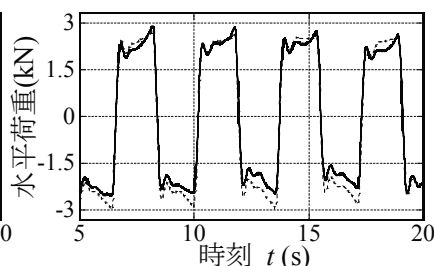

(b) $\pm 180 \mathrm{~mm}, 0.28 \mathrm{~Hz} ， 三$ 角波

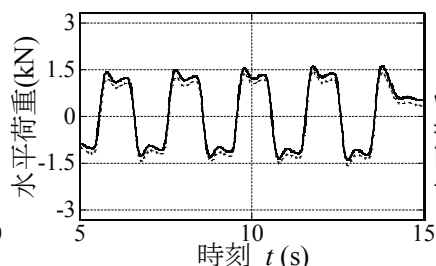

(c) $\pm 20 \mathrm{~mm}, 0.5 \mathrm{~Hz}$ ，三角波

図 6 水平荷重時刻歴

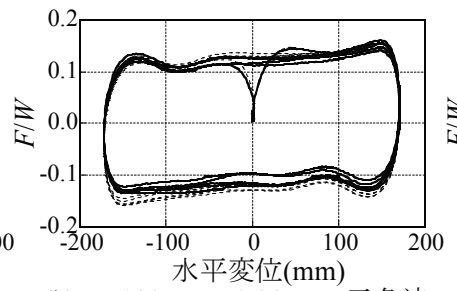

(b) $\pm 180 \mathrm{~mm}, 0.28 \mathrm{~Hz}$, 三角波

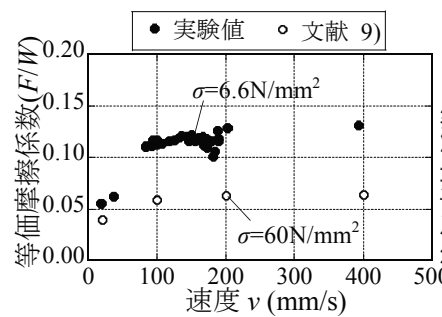

図 8 等価摩擦係数一速度関係

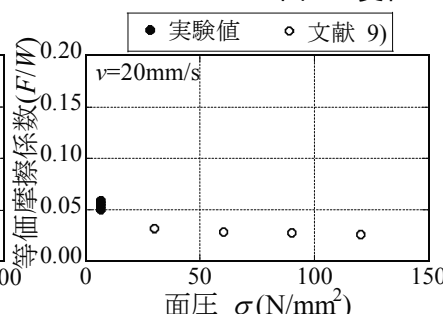

図 9 等価摩擦係数一面圧関係

用いている。図 9 を見ると, 等価摩擦係数は高面圧の場合では 0.06 程度に収束する一方で, ごく低面圧では倍程度に大きくなる傾向が みられる。また, 図 8 に見るように, 速度の増加により等価摩擦係 数が増加する速度依存性も, 低面圧の方がより顕著になっているこ とがわかる。

\section{SSB 付架構振動台実験}

次に, ロードセルを取り外し試験体架構が自由振動できるよう

にして振動台実験を行い, 重量偏心および浮き上がりが生じた際の SSB の応答性状を確認する。

\section{1 重量均等振動台実験}

まず，全ての柱に錘を 5 枚ずつ積載した重量均等状態での振動台 実験を行う。写真 1 にセットアップ状況を示す。測定項目は動的加 振実験同様, 歪ゲージより評価した層せん断力および SSB 水平相対 変位とし, 加えて SSB の鉛直変位も図 5 における (X1, Y1) の位置 について測定する。表 2 に載荷項目を示す。地震波は最大速度が概 ね $500 \mathrm{~mm} / \mathrm{s}$ となるよう設定した。

図 10 に載荷 No.13 (正弦波, 振幅 $30 \mathrm{~mm}$ ) の振動数 $1.3 \mathrm{~Hz}$ 近傍にお ける加速度時刻歴および水平変位一等価摩擦係数関係を示す。(a) より試験体架構の応答加速度は入力と同等の $1500 \mathrm{~mm} / \mathrm{s}^{2}$ 程度に抑制 されていることが分かる。最大入力加速度が $1500 \mathrm{~mm} / \mathrm{s}^{2}$ 以下の入力 ではSSB は滑動せず，振動台と試験体架構が一体化し振動した。(b) に見るように, 最大速度での等価摩擦係数は $0.11 \sim 0.13$ 程度であり, この時点の速度は $250 \mathrm{~mm} / \mathrm{s}$ 程度であることから, 図 8 で示した等価 摩擦係数と速度の関係と概ね一致していることが分かる。また, 図 7 に比べ履歴の角が大きく落ち, 矩型から丸型になっており, 正弦 波入力による SSB の速度依存性が顕著に表れている。図 11 に地震 波入力における水平変位一等価摩擦係数関係を示す。図 10 と同様に

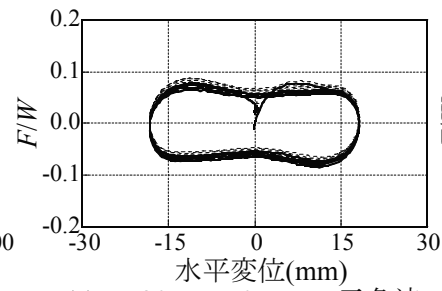

(c) $\pm 20 \mathrm{~mm}, 0.5 \mathrm{~Hz}$, 三角波 摩擦係数関係

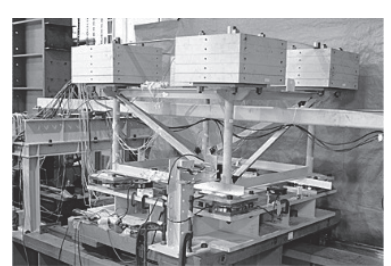

写真 1 重量均等セットアップ

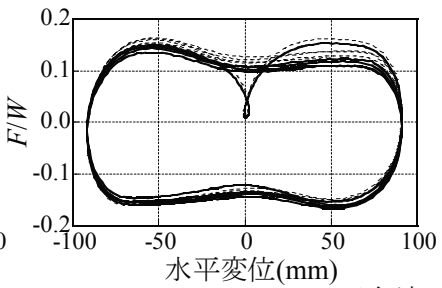

(d) $\pm 100 \mathrm{~mm}, 0.5 \mathrm{~Hz}$, 三角波

表 2 重量均等実験載荷項目

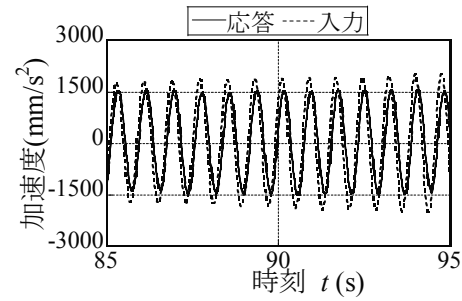

(a) 加速度時刻糜

加速度時刻歴 (b) 水平変位一等価摩擦係数関係

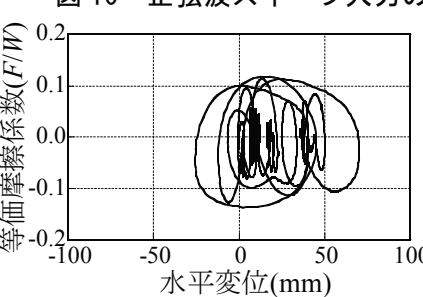

(a) El Centro $140 \%$

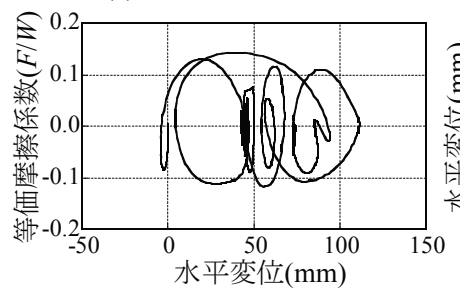

(b) JMA Kobe $50 \%$

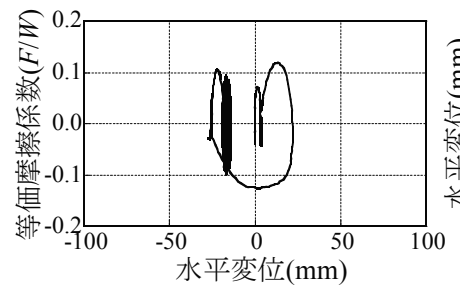

(c) Hachinohe 140\%
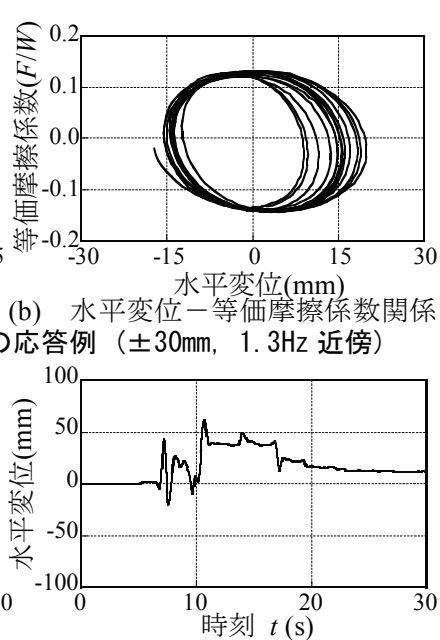

(a) El Centro $140 \%$

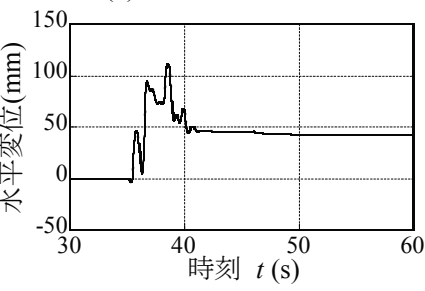

(b) JMA Kobe $50 \%$

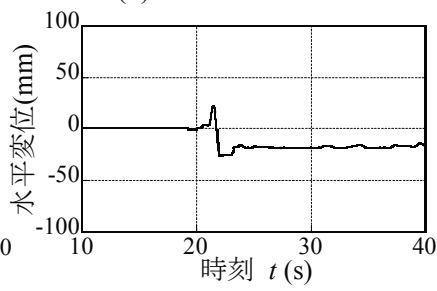

(c) Hachinohe 140\%
図 11 水平変位一等価摩擦係数関係 図 12 応答水平変位時刻歴 
履歴ループは丸みを帯び, 最大等価摩擦係数は最大 0.14 程度で安定 している。図 12 に地震波入力に対する応答水平変位時刻歴を示す。 いずれの地震波においても若干の残留変位が残っている。これは試 験体重量が小さく低面圧のため滑り出しの等価摩擦係数が高く, 原 点回帰に十分な復元力が得られない影響によると考えられる。また, パルス的地震波である JMA Kobe に比べ, 他の 2 地震波では残留変 位が抑えられている。同様に地震後に残留変位が残った場合でも, その後微振動を受けることで残留変位が解消寸る性状が見られた。

\section{2 重量偏心振動台実験}

続いて前節のセットアップから, Y2 構面の錘を 4 枚ずつ取り除い た重量偏心状態での振動台実験を行う。試験体重量比は, Y1 構面 : Y2 構面=3: 1 となる。写真 2 にセットアップ状況を示す。測定項目, 載荷項目は重量均等実験と同様である。また，㧖れ応答の評価とし て, 図 13 に示すように㨭れ角 $\psi$ を定義する。㧖れ角 $\psi$ は支承部水 平変位 $\delta_{i}$, 測定点間距離 $L$ を用いて, 式 (3) により表す。

$$
\psi=\left(\delta_{1}-\delta_{2}\right) / L
$$

図 14 に地震波入力における水平変位一等価摩擦係数関係を, 重量 均等実験と比較して示す。重量偏心と均等では概ね同等の応答結果 が得られており, 重量偏心下でもSSB が免震装置として均等時と同 等に機能することが分かる。図 15 に据れ角時刻歴を, 重量均等実験

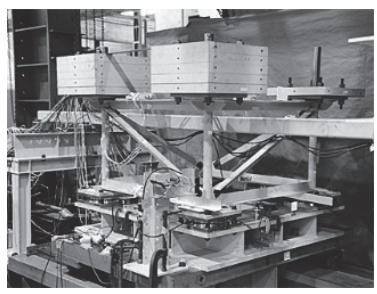

写真 2 重量偏心セットアップ

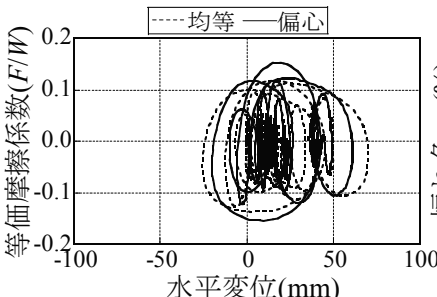

(a) El Centro $140 \%$

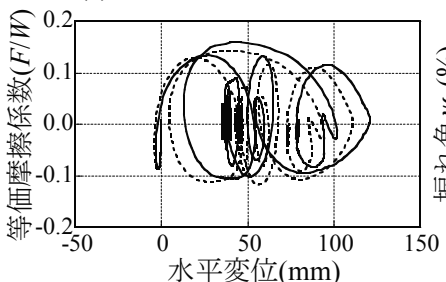

(b) JMA Kobe $50 \%$

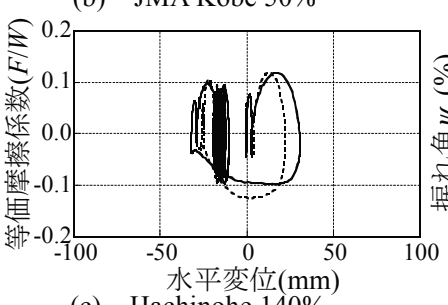

(c) Hachinohe $140 \%$

図 14 水平変位一等価摩擦係数関係

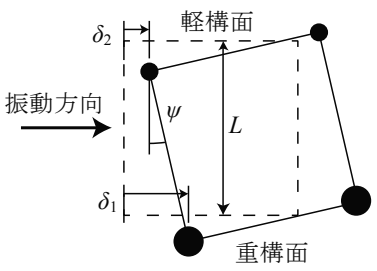

図 13 重量偏心振動台実験

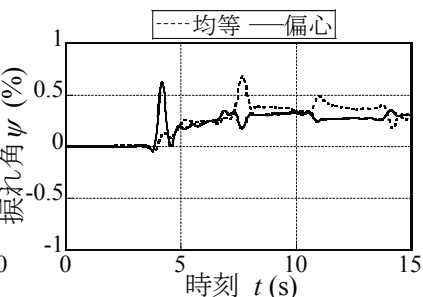

(a) El Centro $140 \%$

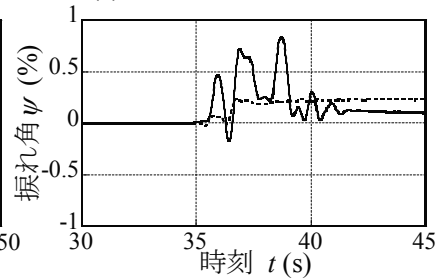

(b) JMA Kobe $50 \%$

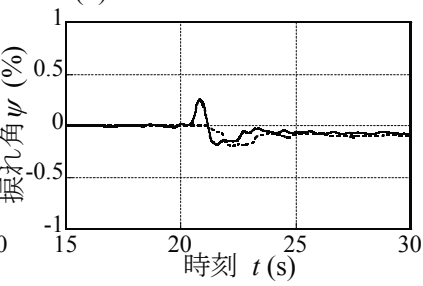

(c) Hachinohe $140 \%$

図 15 㨝れ角時刻歴
と比較して示す。重量偏心では $0.5 \% \mathrm{rad}$ 程度の㧖れ角が生じている が，これは後述するSSB の芯ずれによると考えられる重量均等時の 㧖れと同程度の微小なものであり，重量偏心の影響による捩れ応答 の卓越は明確には見られなかった。

\section{3 浮き上がりを伴う振動台実験}

本節では試験体を入力方向に対し $45^{\circ}$ 回転させ, 浮き上がりを伴 う振動台実験を行う。隅柱の錘を除荷し浮き上がらせる隅柱除荷と， 錘を全ての柱に 5 枚ずつ積載し浮き上がらせない均等積載の 2 種類 の試験行い, 両者の結果を比較する。写真 3 に隅柱除荷のセットア ップ状況を示す。隅柱除荷ではブレースを 2 構面取り外し, 架構の 剛性を偏心させることで図 16 に示すように浮き上がりを誘発させ る。図 17 に測定位置と併せて, 隅柱除荷位置およびブレース取り外 し位置を示す。測定項目は重量均等実験と同様であり, 載荷は表 2 に示した地震波のみを行う。

図 18 に得られた水平変位一等価摩擦係数関係を示す。横軸の変位 は図 17 に示す水平変位計の平均值である。均等積載と隅柱除去を比
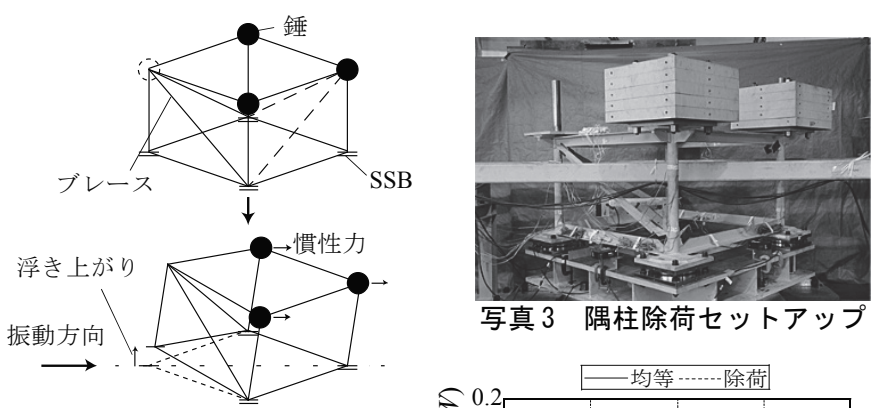

図 16 浮き上がり変形モード

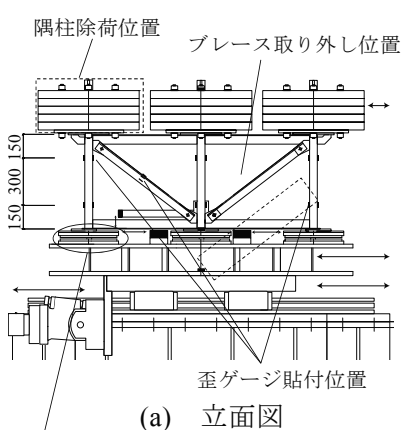

(a) 立面図
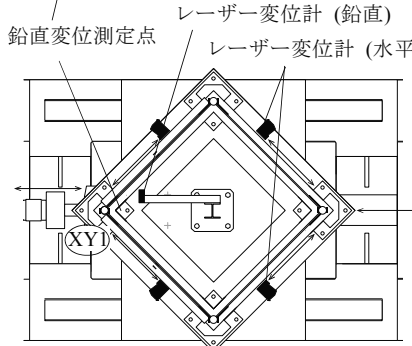

(b) 平面図

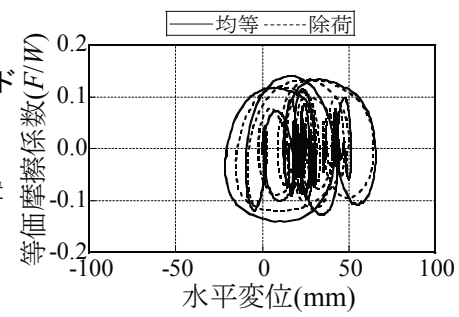

(1) El Centro $140 \%$

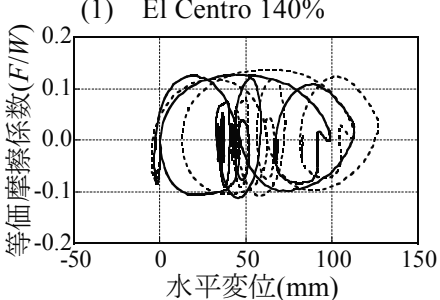

(2) JMA Kobe $50 \%$

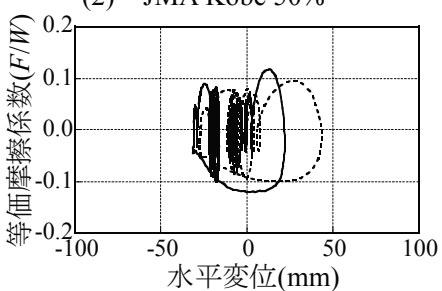

(3) Hachinohe $140 \%$

図 17 測定位置

図 18 水平変位一等価摩擦係数関係

最低点のずれ $R \theta$

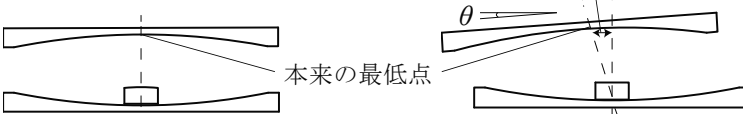

図 19 水平精度の誤差による最低点のずれの概略図 
較すると, Hachinohe 波等では最大変位で 4 割程度, 等価摩擦係数 で 1 割程度の差が生じる場合があるが, 両者は入力波ごとに概ね類 似の履歷形状と位相を示す。

次に図 17 中の XY1 点の鉛直変位を確認する。本実験においては 図 19 に示すように, SSB 取付けの水平精度の誤差 $\theta$ によりコンケ イブプレートの最低点が中心からずれた位置よりスタートしている 場合がある。誤差は各支承部 $25 \sim 50 \mathrm{~mm}$ 程度で $\theta$ の值が 1/200 1/100 rad の場合に相当する。鉛直変位のグラフにおいては各 支承部でこの誤差を補正した計算值を鉛直変位として評価する。

図 20 に鉛直変位オービットを示す。補正計算値は均等積載の值と よく対応している。一方，均等積載に比べ隅柱除荷では鉛直変位は 均等積載および補正計算値を上回った值となっている。この測定さ れた鉛直変位と補正計算值の差を推定浮き上がり量として評価する。 図 21 に推定浮き上がり量の時刻歷を示す。同図を見るとそれぞれの 地震波で $0.4 \sim 0.8 \mathrm{~mm}$ の浮き上がりが生じており, 鉛直残留変位も 微小ながら確認される。浮き上がりが生じることで, 支承部では図 22 に示寸ような空走が生じることがビデオより観察された。その際， スライダーが本来の位置からずれ, 図 21 に示すように残留鉛直変位 が生じると考えられる。また, 推定浮き上がり量がピークを記録し た同時刻において，SSBの上下コンケイブプレート間に挿入したフ アイバースコープにより，SSB 上部が空走する様子が確認された。 その一方, 図 18 で述べたように水平応答に関しては浮き上がりの影 響は小さく免震効果自体はあまり変化していないと言える。鉛直残 留変位も引き続く加振により, スライダーが本来の位置に戻ること で解消する様子が観察された。

\section{SSB カ学モデルの提案と応答解析}

本章では前章での実験結果を踏まえ, 摩擦係数の速度および面圧 依存性を考慮した SSB 力学モデルを構築し, 実験結果の再現を試み る。力学モデルとして, これまで一般的に摩擦履歴型のモデルに用 いられてきたバイリニア型の弾塑性要素 ${ }^{10)}$ に加え, 粘性要素を組み 合わせたモデルを提案する。

\section{1 SSB カ学モデルの構築}

SSB では中村ら ${ }^{9}$ の研究により式 (4) に表される摩擦係数の関係 式が提案されている。右辺下線部は面圧依存性, 二重線部は速度依 存性を表している。

$$
\mu^{\prime}-\mu_{0} \times\left(1.746 \sigma^{-0.141}+0.02\right) \times \underline{\left(1-0.55 e^{-0.019 v}\right)}
$$

ここに $\mu^{\prime}$ : 摩擦係数, $\mu_{0}$ : 基準摩擦係数 $(0.047), \sigma$ : スライダー に作用する面圧， $v: \mathrm{SSB}$ 上部の速度である。

上記の摩擦係数評価式(4)は実大高面圧載荷実験時の 3 サイクル目 の履歴に基づき同定されたもので，スライダーの摩擦熱による温度 上昇の影響を含んだものとなっている。今回の縮小実験における摩 擦係数の変化は, 低面圧であることが主体であるが, 式(4)で対象と した試験体よりスライダーが小さく発生する温度上昇が少ない影響 も受けていると考えられる。従って評価式は最終的に面圧, 速度, 温度の 3 つのパラメータにより表現することが求められるが, 温度 はスライダー径, 相対移動速度や移動量, 周辺部材の熱伝導率等の 複雑な関数になっていると考えられ, 現段階の知見では温度上昇の 影響を完全に式として分離し表現することは困難である。このこと

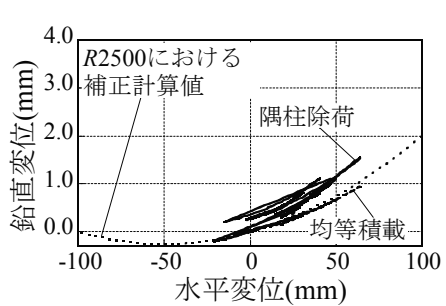

(a) El Centro $140 \%$

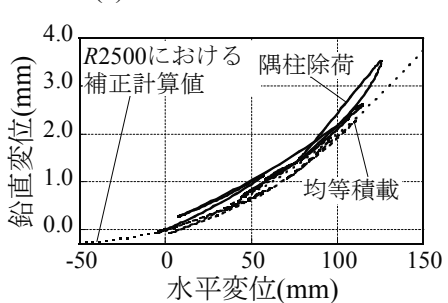

(b) JMA Kobe $50 \%$

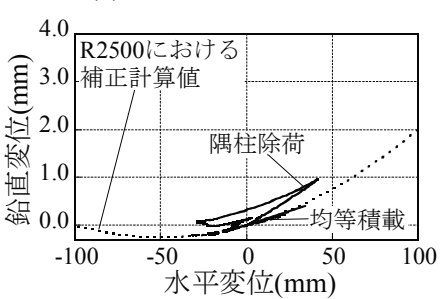

(c) Hachinohe $140 \%$

図 20 鉛直変位オービット

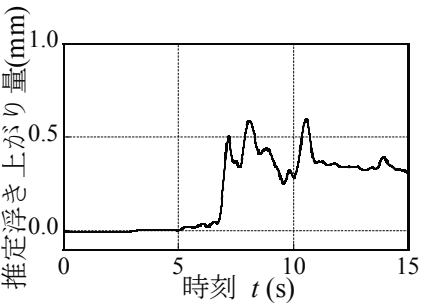

(a) El Centro $140 \%$

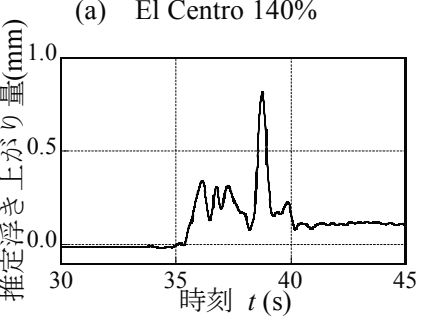

(b) JMA Kobe $50 \%$

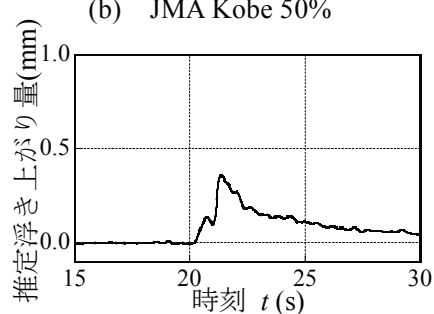

(c) Hachinohe $140 \%$

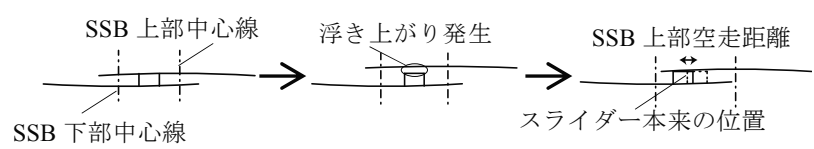

図 22 スライダー空走時概略図

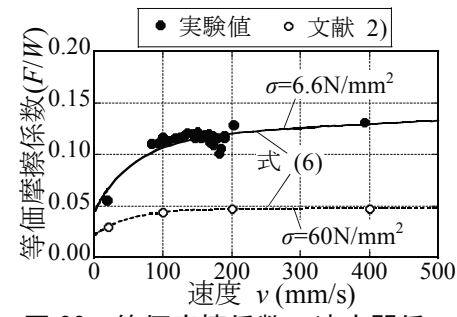

図 23 等価摩擦係数一速度関係

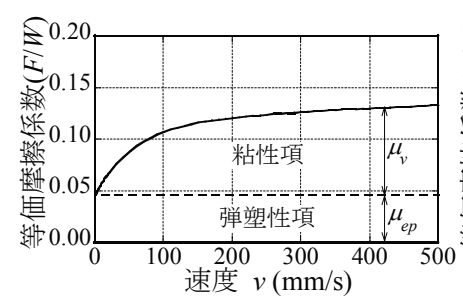

図 25 SSB モデル $\mu-v$ 関係 (面圧 $6.6 \mathrm{~N} / \mathrm{mm}^{2}$ )

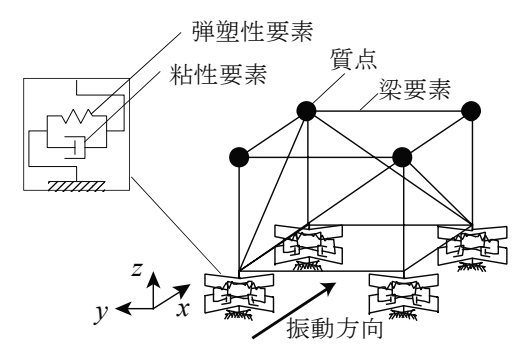

図 27 解析モデル

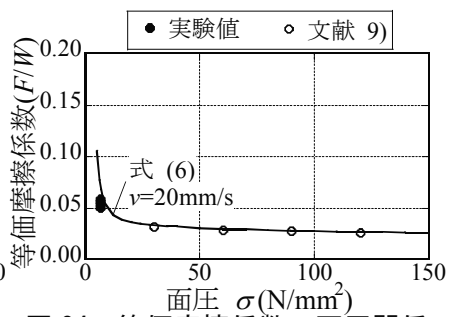

図 24 等価摩擦係数一面圧関係

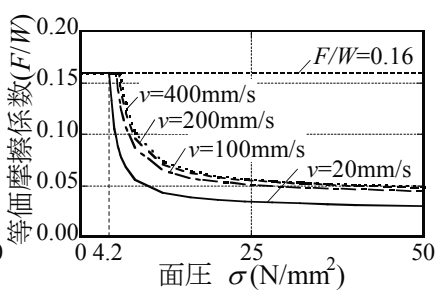

図 26 SSB モデル $\mu-\sigma$ 関係

表 3 提案履歴モデル 面圧条件

\begin{tabular}{|c|c|c|}
\hline & $\sigma\left(\mathrm{N} / \mathrm{mm}^{2}\right)$ \\
\hline \multicolumn{2}{|c|}{ 重量均等 } & 6.6 \\
\hline 重量 & 重構面 & 4.3 \\
偏心 & 軽構面 & 1.9 \\
\hline
\end{tabular}




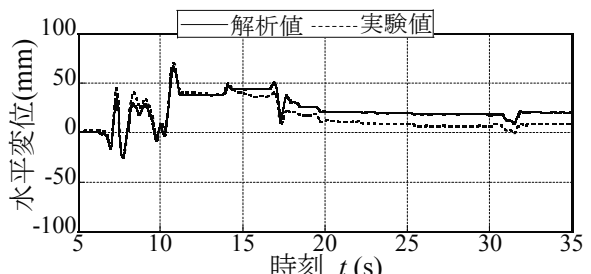

(a) El Centro $140 \%$

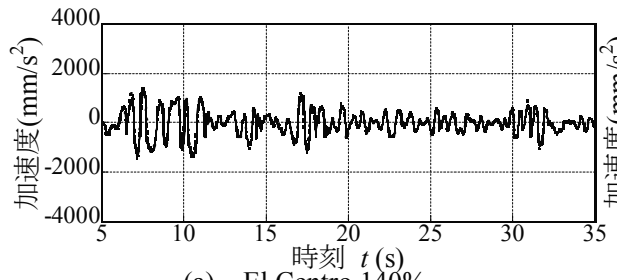

(a) El Centro $140 \%$

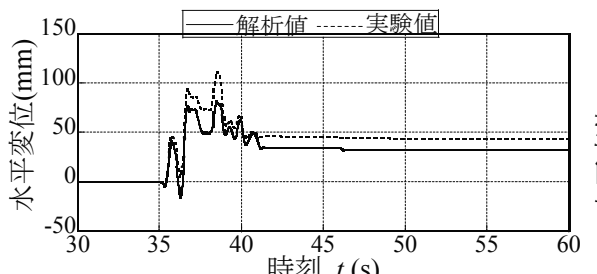

(b) JMA Kobe $50 \%$

図 28 応答変位時刻歴

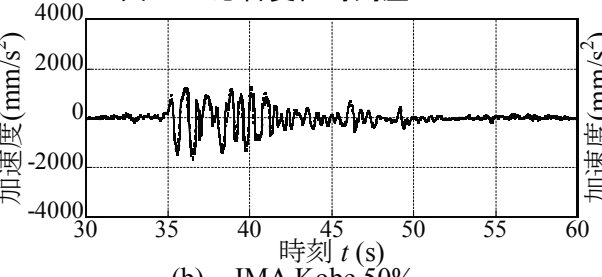

(b) JMA Kobe $50 \%$

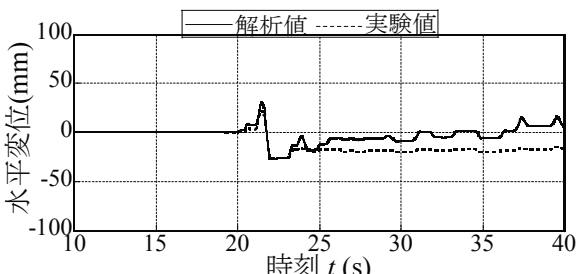

(c) Hachinohe $140 \%$

図 29 応答加速度時刻歴

から，今回は上記の効果を圧力，速度の関数として帰納的に同定し 式(5)の補正関数で表し，摩擦係数を式 (6) で表現する。

$$
\begin{aligned}
& \alpha_{L}=e^{\left(20+v^{04}\right) / \sigma^{2}} \\
& \mu(\sigma, v)=\mu_{0} \times\left(1.746 \sigma^{-0.141}+0.02\right) \times\left(1-0.55 e^{-0.019 v}\right) \times e^{\left(201+v^{04}\right) / \sigma^{2}}
\end{aligned}
$$

図 8，9 で示した等価摩擦係数と速度および面圧関係に式 (6) を 合わせプロットしたものを図 23，24に示す。式 (6) は実験值とよ く対応していることが分かる。上記のように, テフロン系の摩擦材 には摩擦係数が速度に依存し変化する特性がある。本特性を履歴モ デルに反映させる手法としては，1）弾塑性モデルにおいて速度に応 じ摩擦係数を変化させる,2) 弾塑性項と粘性項を組合せて表現する, 等が考えられる。過去の文献では 1) の手法が取られることが多い が，本研究では 2）の手法で速度依存性を表現することを試みその 精度を確認寸る。具体的には式 (6) を用い, 図 25, 26に示すように, 摩擦係数 $\mu(\sigma, v)$ と速度 $v$ および面圧 $\sigma$ の関係を, 弾塑性要素と粘性 要素にて同定した履歴モデルを構築する。バイリニア型の弾塑性要 素は降伏耐力を式(7) に表す $\mu_{e p}(\sigma)$ とし, 二次剛性 $K$ により決まる 固有周期が 4.5 秒となるよう設定する。粘性要素は式 $(8)$ に表す $\mu_{v}(v)$ をトリリニアに近似することで設定する。なお，本論での提案履歴 モデルにおいては二方向応答および応答による面圧変動の影響は考 慮していない。

$$
\begin{aligned}
& \mu_{\mathrm{cp}}(\sigma)=\mu_{0} \times\left(1.746 \sigma^{-0.141}+0.02\right) \times 0.45 \times e^{20 / \sigma^{2}} \\
& \mu_{\mathrm{v}}(v)=\mu-\mu_{\mathrm{ep}}
\end{aligned}
$$

\section{2 実験の再現}

本節では, 前節で構築した提案履歴モデルを用いて，3 章で実施 した振動台実験と同様の応答解析を行い, 重量均等および重量偏心 実験の再現を試みる。図 27 に解析モデルを示す。表 3 に, 重量均等 と偏心それぞれの提案履歴モデルにおける面圧条件を示す。

提案履歴モデルを用いて得られた解析結果のうち, 図 28 に応答変 位時刻歷を, 図 29 に応答加速度時刻歴を実験結果と比較しそれぞれ 示す。両者は概㸚良い対応を示しており, 特に加速度は高い精度で 対応している。重量偏心のケースについても同様に良い対応が得ら れた。図 30 に重量均等の水平变位一等価摩擦係数関係を示す。パル ス波に近いJMA Kobe 波では最大応答変位に 3 割程度の差があるが， 各地震波入力において概衫実験值に近い特性が得られている。解析 值においても丸型に近づいた履歴をしており，粘性要素を組み合わ

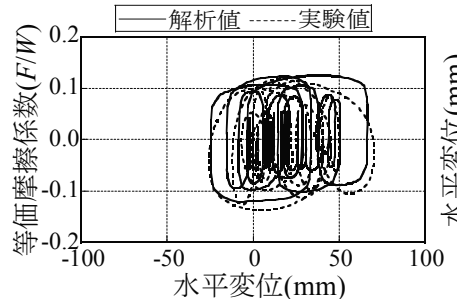

(a) El Centro $140 \%$

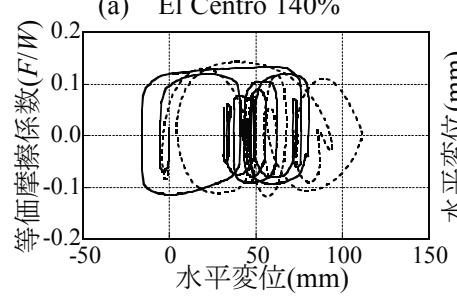

(b) JMA Kobe $50 \%$

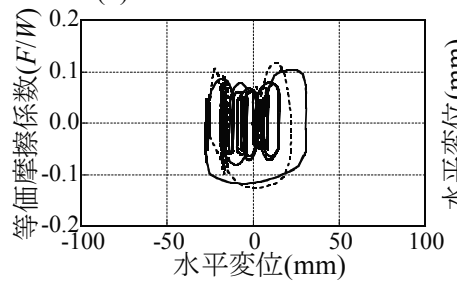

(c) Hachinohe $140 \%$

図 30 水平変位一等価摩擦係数関係 (重量均等)

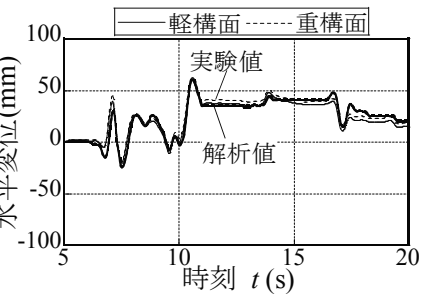

(a) El Centro $140 \%$
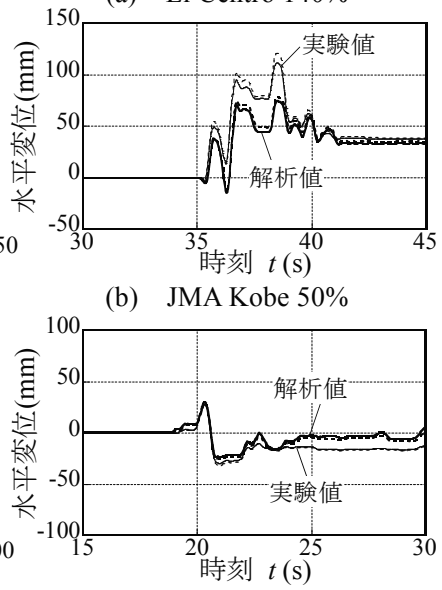

(c) Hachinohe $140 \%$ (重量偏心) (b) JMA Kobe $50 \%$

図 31 応答変位時刻歴

せたことで履歴に速度依存性が再現されていることが分かる。図 31 に重量偏心の応答変位時刻歴を示す。面圧条件を構面ごとに変えた 場合でも，提案履歴モデルは実験值とよく対応した応答を示してい る。

以上, 各種解析值と実験值の対応より, 提案履歴モデルは実験を 概初再現できており，SSB のモデル化として有効と判断される。な お，本事例では低面圧振動台実験を再現しているが，図 23 に見るよ うに面圧が高くなると速度依存性は低下し，粘性項の影響は小さく なることが予想される。

\section{5. 結}

本研究では, 偏心や浮き上がりを伴うSSB 付架構の縮小振動台実 験を実施し，その応答性状の分析を行った。また，得られた結果よ り SSBの履歴モデルを構築し, 提案したモデルを用いて実験結果の 再現を行った。得られた知見を以下に示す。 
1) 本実験では, 基準面圧の約 $1 / 10$ の低面圧下において摩擦係数が 高面圧の基準值より倍程度大きくなり, 速度の上昇による摩擦 係数の増加もより顕著になる特性が確認された。

2) 重量を偏心させた場合の最大㧖れ応答值は重量均等と同等程度 に留まり，㧖れ応答の増幅はあまり見られなかった。

3) 浮き上がりが生じた際, 支承部ではスライダーの空走が確認さ れ，残留変位がやや大きくなる傾向が見られたが，水平応答履 歴に対する影響はあまり見られなかった。

4) 摩擦係数を評価するにあたり，低面圧および温度上昇が少ない 影響を補正関数で表わ寸ことで、実験結果の再現精度を高める ことができた。さらに摩擦係数の速度依存性を粘性項で表現し, バイリニア型の弾塑性要素と粘性要素を組み合わせた履歴モデ ルを提案し，実験結果を概ね再現できることを示した。

\section{謝辞}

本研究を進めるにあたり，新日鉄住金エンジニアリング株式会 社 : 長谷川久巳氏, 株式会社ダイフク : 井上秀氏, 西雄士氏に貴重 なご意見を頂いた。ここに深謝したい。
参考文献

1) Anoop Mokha, M. C. Constantinou, A. M. Reinhorn, Victor A. Zayas : Experimental Study of Friction-Pendulum Isolation System, Journal of Structural Engineering, ASCE, Vol. 117, No.4, pp.1201-1217, 1991.4

2) D. M. Fenz, M. C. Constantinou : Behavior of the double Concave Friction Pendulum Bearing, Earthquake Engineering and Structural Dynamics, No.35, pp.1403-1424, 2006.6

3) M. Constantinou, A. S. Whittaker, E Velivasakis : Seismic Evaluation and Retrofit of the Ataturk International Airport Terminal Building, Research Progress and Accomplishments : 2000-2001, MCEER Bulletin.

4) A. S. Mokha, P. L. Lee, X. Wang, P. Yu : Seismic Isolation Design of the New International Terminal at San Francisco International Airport, Conf. Struct. Eng. In the 21st Century, 1999

5) 李 同生,下田 郁夫, 長田 修: 球面すべり支承を用いた免震装置の開発, 球面すべり支承に用いる摩擦材の摩擦性能について, 日本建築学会大会 学術講演梗概集, B 構造 I, pp.609-610, 1991.8

6) 小野 英雄ほか: 球面すべり支承を用いた原子炉建屋の動的振動特性の検 討, 日本建築学会大会学術講演梗概集, 構造 II, pp.1259-1260, 2012.9

7) 鯉淵崇任, 斉藤賢二, 栗田哲, 千葉大輔：地震応答記録に基づいた球面 滑り支承の低速度時の復元力特性, 日本建築学会東北支部研究報告集. 構造系 (68), pp.105-108, 2005.6

8) M. C. Constantinou, Anoop Mokha, Andrei Reinborn : Teflon Bearings in Base Isolation.II : Modeling, Journal of Structural Engineering, ASCE, Vol.116, No.2, pp.455-474, 1990.2

9) 中村秀司，西本晃治，富本淳 : 球面す心゙り支承 NS-SSB $®$ 開発，新日鉄 住金エンジニアリング技報，Vol.6，pp.28-35，2015

10) 川島一彦：動的解析における摩擦力のモデル化に関する一考察，土木学 会論文報告集，第 309 号，pp.151-154，1981.5

11) 高橋良和, 日比雅一, 家村浩和：各種依存性を考慮した滑り型免震支承 の数值モデルに関する一考察, 応用力学論文集, Vol.8, pp.701-708, 2005.8 


\title{
SHAKING TABLE TESTS ON SPHERICAL SLIDING BEARINGS TAKING ECCENTRICITY AND UPLIFT INTO ACCOUNT
}

\author{
Toru TAKEUCHI ${ }^{* 1}$, Hideji NAKAMURA ${ }^{* 2}$, Masakaze UCHIDA*3, \\ Michiyasu YOSHIDA*3 and Ryota MATSUI*4 \\ ${ }^{* 1}$ Prof., Dept. of Arch. and Build. Eng., Tokyo Institute of Technology, Dr.Eng. \\ ${ }^{* 2}$ Nippon Steel Sumikin Engineering. \\ ${ }^{* 3}$ Graduate Student, Tokyo Institute of Technology. \\ ${ }^{* 4}$ Assist. Prof., Dept. of Arch. and Build. Eng., Tokyo Institute of Technology, Dr.Eng.
}

\section{Introduction}

Although rubber bearings are popular for seismic isolation bearings in Japan, Spherical Sliding Bearings (SSB) or Friction Pendulum Bearings (FPB) are also widely used in many countries including U. S. In this paper, shaking table tests on braced frame supported by SSB are carried out, and their dependency on pressure and velocity is researched. Also tests with the eccentric dead loads are conducted, including uplift actions at bearings. Analytical models taking pressure and velocity dependency into accounts are proposed, and their validity against the experimental results and discussed.

\section{Dynamic Tests on Reduced-scale Frame with SSB Bearing}

A simplified frame with mass on the top supported by four numbers of one-third scale SSB bearings are constructed and placed on shaking table, and the upper frame is connected to reaction frame through a load-cell. Then shaking table is moved in various amplitudes between $20 \mathrm{~mm}$ to $180 \mathrm{~mm}$, and frequencies between $0.02 \mathrm{~Hz}$ to $0.5 \mathrm{~Hz}$, in sine waves and triangular waves. From the test results, dependency of equivalent friction ratio on pressure and velocity is examined. The shear forces introduced in the frame is measured by strain gauges attached on the frame are compared with the reaction forces by the load-cell, confirming the validity of evaluating the shear force by strain gauges.

\section{Shaking Table Tests of SSB frames with Various Conditions}

Next, SSB frame is placed free on the shaking table, and dynamic behavior under various seismic inputs are studied. After confirming the response reduction effects by SSB bearings under full-mass distribution, response characteristics under eccentric mass-distributions are researched. Under all types of seismic input, rotational responses are very limited, and effects of eccentric loadings found to be small. Next, frame is rotated 45 degree and uplift actions at the corner bearing are produced to confirm the action of slider under separation of concave plates. Under JMA-Kobe wave, the maximum uplift around $0.8 \mathrm{~mm}$ is observed with free-sliding at the upper plate. Although some residual deformations are remained after the uplift, very limited effects on the hysteresis and the maximum response were observed.

\section{Proposal of Hysteresis Model for SSB Taking Velocity and Pressure Dependency into Account}

Based on the results obtained by the experiments, hysteresis model for SSB taking velocity and pressure dependency into accounts is proposed. Basic friction hysteresis is modeled as elasto-plastic hysteresis referring the past studies, and then velocity dependency is added as dash-pot model proportional to the velocity. The proposed model well explains the various dependencies measured in the dynamic tests. An analytical frame model including the proposed hysteresis for SSB is constructed and the response against the seismic inputs as same as the shaking table tests are calculated by time-history analyses and compared with those by the experiments. As a result, the response time-histories and reaction force displacement relationships well agreed each other, including the eccentric load conditions. Therefore, the proposed hysteresis model is considered to be valid.

\section{Conclusion}

As conclusions, the following results are obtained.

1) SSB bearings showed pressure dependency lower than $50 \mathrm{~N} / \mathrm{mm}^{2}$, and velocity dependency which increases under low pressure.

2) Effects of eccentric loadings are limited, and the responses are also not affected under uplift actions, except for some residual deformations after the shake.

3) The proposed hysteresis model taking pressure and velocity dependencies well explain the results of shaking table test results. 